in vivo 34 : $953-964(2020)$

doi:10.21873/invivo.11863

Review

\title{
Pathophysiological Changes During Ischemia-reperfusion Injury in Rodent Hepatic Steatosis
}

\author{
ANNA-AIKATERINI NERI ${ }^{1}$, ISMENE A. DONTAS ${ }^{1}$, \\ DIMITRIOS C. ILIOPOULOS ${ }^{2}$ and THEODORE KARATZAS ${ }^{2,3}$ \\ ${ }^{1}$ Laboratory for Research of the Musculoskeletal System "Th. Garofalidis", \\ KAT Hospital, School of Medicine, National \& Kapodistrian University of Athens, Kifissia, Greece; \\ ${ }^{2}$ Laboratory of Experimental Surgery \& Surgical Research "N.S. Christeas", \\ School of Medicine, National \& Kapodistrian University of Athens, Athens, Greece; \\ ${ }^{3} 2^{\text {nd }}$ Department of Propedeutic Surgery, School of Medicine, \\ National \& Kapodistrian University of Athens, Athens, Greece
}

\begin{abstract}
Background/Aim: Ischemia and reperfusion injuries may produce deleterious effects on hepatic tissue after liver surgery and transplantation. The impact of ischemia-reperfusion injury (IRI) on the liver depends on its substrate, the percentage of liver ischemic tissue subjected to IRI and the ischemia time. The consequences of IRI are more evident in pathologic liver substrates, such as steatotic livers. This review is the result of an extended bibliographic PubMed search focused on the last 20 years. It highlights basic differences encountered during IRI in lean and steatotic livers based on studies using rodent experimental models. Conclusion: The main difference in cell death between lean and steatotic livers is the prevalence of apoptosis in the former and necrosis in the latter. There are also major changes in the effect of intracellular mediators, such as TNF $\alpha$ and $I L-1 \beta$. Further experimental studies are needed in order to increase current knowledge of IRI effects and relevant mechanisms in both lean and steatotic livers, so that new preventive and therapeutic strategies maybe developed.
\end{abstract}

This article is freely accessible online.

Correspondence to: Anna-Aikaterini Neri, Laboratory for Research of the Musculoskeletal System "Th. Garofalidis", KAT Hospital, School of Medicine, National \& Kapodistrian University of Athens, 10 Athinas Street, Kifissia 14561, Greece. Tel: +30 6970448434, e-mail: anaikneri@gmail.com

Key Words: Liver injury, ischemia-reperfusion injury, hepatic steatosis, pathophysiological changes, oxidative stress, cytokines, review.
Fatty liver disease represents a very common disorder with a global prevalence of $25 \%$, and a rate of $20-30 \%$ in developed countries and up to $95 \%$ among the obese population. The existence of hepatic steatosis is a critical factor for liver surgery and transplantation and has aggravating effects when associated with ischemia-reperfusion injury (IRI) (1-7). Hepatic steatosis is associated with an operative mortality higher than $14 \%$ after extended liver resection, in contrast to $2 \%$ in patients with lean livers (8-11).

IRI refers to the enhanced cellular damage inflicted on a hypoxic liver following blood flow restoration observed in major liver resections and transplantation. Ischemiareperfusion (IR) maneuver, which is applied to minimize blood loss during surgery, has detrimental effects on the liver due to ischemia (12-15). IR phenomena are present after restoration of reduced blood flow as a result of shock, hypotension, hypoxemia and secondary low blood flow due, for instance, to congestive heart failure (16-18). The liver substrate, the percentage of liver tissue undergoing ischemia and the duration of ischemia are critical for the viability of the hepatic tissue.

\section{Pathophysiological Changes}

The different reaction of the fatty liver to IRI is linked to its decreased ability to restore adenosine triphosphate (ATP) levels after IR stress, and its increased sensitivity to proinflammatory factors (19). Liver becomes steatotic via chronic overfeeding, triglycerides' excess, gradual increase in the deposition of adipose tissue and adipocyte hypertrophy, as well as endoplasmic reticulum stress. The activation of apoptotic and inflammatory pathways results in increased concentration of hepatic stellate cells (HSCs) and Kupffer 
cells (KCs), which differentiate to myofibroblasts and lead to fibrosis (20). Selzner et al. have claimed that the augmented sensitivity of fatty liver is due to changes in the onset of apoptotic cell death and the types of cell death. Specifically, the main type of cell death in lean ischemic liver is rapid apoptosis, while its onset is delayed in fatty ischemic liver (10). Apoptosis requires adenosine triphosphate (ATP) and when ATP is depleted, apoptosis switches to necrosis (21). Apoptosis remains the main type of cell death in lean liver where necrosis is minimal (18\%). On the other hand, fatty liver is characterized by moderate apoptosis and massive necrosis $(73 \%)$. The difference between these livers has also been confirmed in experimental rat studies by evaluation of intracellular mediators of apoptosis; when the livers were subjected to 60 minutes of total hepatic ischemia, the rats with fatty livers died within 3 days, whereas those with normal livers survived 30 days $(8,10,22)$.

Tiriveedhi et al. have demonstrated that even the proteome profiles of livers with steatosis subjected to IRI, are significantly different compared to lean livers (23).

During the ischemia phase, oxygen, glycogen and ATP are depleted, resulting in intracellular metabolic changes and the so-called "pH paradox". In the early phase, due to the initiation of necrosis, intracellular $\mathrm{pH}$ drops so that hepatocytes are protected. Normalization of intracellular $\mathrm{pH}$ upon reperfusion, however, accelerates hepatocytes' death. The supremacy of pro-oxidants characterizes the intermediate phase, while inflammatory and adhesion molecules the late phase $(24,25)$.

In the first two hours of reperfusion, oxidative stress is dominant. Activated endothelial cells of microvessels generate additional reactive oxygen species (ROS) and less nitric oxide (NO), causing immediate cellular injury (24-26). The subsequent imbalance between superoxide and NO in endothelial cells leads to an increase in pro-inflammatory factors (25). During the following 6-48 hours of reperfusion, activated neutrophils injure hepatocytes via inflammatory mechanisms mediating the release of ROS, elastase, cathepsin $\mathrm{G}$, heparinase, collagenase and hydrolytic enzymes $(24,26)$.

Frequently encountered pathophysiological changes and differences between lean and steatotic livers regarding mainly IRI, are described below. The main parameters that increase are listed in Table I.

Mitochondrial injury generally leads to cell necrosis and apoptosis in IRI. i. Mitochondria uncoupling protein-2 (UCP2) expression is normally cytoprotective when augmented by mitochondrial superoxide production. Nevertheless, during IR, UCP2 expression promotes hepatocyte injury. This is more evident in steatotic hepatocytes that contain higher levels of superoxide and $\mathrm{H}_{2} \mathrm{O}_{2}$. UCP2 higher levels in steatotic hepatocytes are also related to ATP depletion and to IRI (26-31). Evans ZP and his coworkers have concluded that UCP2 renders steatotic
Table I. Parameters considerably increased in rodent models of steatotic liver after IRI.

\begin{tabular}{lc}
\hline Parameters & References \\
\hline Mitochondria uncoupling protein-2 & $27-36$ \\
Mitochondrial permeability transition & $37-39$ \\
Reactive oxygen species & $22,40-45$ \\
iNOS gene expression & $46,53-62$ \\
Endoplasmic reticulum stress & $71-76$ \\
Selectins & 79,80 \\
Kupffer cells & $109-114$ \\
Caspases & $10,115-118$ \\
Malondialdehyde & 119,120 \\
Myeloperoxidase & 119,122 \\
Alanine transaminase & $39,86,123,124$
\end{tabular}

livers more sensitive to IRI through the regulation of hepatic ATP levels (31-36). ii. Mitochondrial permeability transition (MPT) is promoted by IR's oxidative stress, increased mitochondrial calcium and inorganic phosphate in lean livers. When a certain amount of calcium accumulates, mitochondria start to swell (36). The permeability of the inner mitochondrial membrane increases, the mitochondrial membrane potential collapses, oxidative phosphorylation is inhibited, ATP is depleted, and apoptosis-induced factors are released. In fatty livers, MPT induction is increased due to the decreased mitochondrial membrane potential $(38,39)$.

ROS. ROS are of great importance both in hepatoprotective mechanisms and during IRI. Recently, endoplasmic reticulum stress has been associated with the production and accumulation of intracellular ROS, which are important mediators of inflammation (40). In the liver, the production of ROS is greater when excessive fat is present, as hepatocytes seem more susceptible to lipid peroxidation and mitochondrial function is disrupted (22, 41-44). According to Prieto I. and Monsalve M., the inability of the steatotic liver to react to ROS is linked to decreased levels of antioxidants, mitochondrial injury, hepatocyte cell death, and the stimulation of mediators of the immune system and profibrosis (45).

Nitric oxide (NO). NO is a diffusible mediator that originates from oxygen and L-arginine through the activity of NO synthase (NOS); it has vasodilating properties that prevent microcirculatory changes imposed by reperfusion, which are more profound in a steatotic liver (46-48). Generally, NO's impact on IRI depends on its concentration, duration and site of production/isoform of NOS that generates it $(46,49,50)$. A small quantity of $\mathrm{NO}$ is considered to decrease tumor cell growth and prostaglandin E2 and F2 alpha (proinflammatory products) levels, while it increases protein synthesis and 
DNA-repair enzymes (51). Specifically, endothelial nitric oxide synthase (eNOS), which functions in the control of vascular tone, increases blood perfusion and therefore protects hepatocytes from IRI $(46,52)$. In contrast, limited quantities of inducible nitric oxide synthase (iNOS) may increase ROS thereby injuring hepatocytes (46, 53-56). Koeppel et al. have shown increased $i N O S$ gene expression after IRI in steatotic liver which was more evident in hepatocytes with fatty degeneration (57). Due to the different actions of iNOS, its expression is regulated by the cooperation of cytokine-inducible transcription factors. Taylor et al. have shown that three cytokines, tumor necrosis factor alpha (TNF $\alpha)$, interleukin-1beta (IL-1 $\beta)$, and interferon-gamma (INF $\gamma$ ), are needed to attain a significant augmentation of iNOS in human hepatocytes (58). Transcription nuclear factor kappa-light-chain-enhancer of activated $\mathrm{B}$ cells $(\mathrm{NF}-\mathrm{kB})$ also relates to iNOS production, in both rodent macrophages and human liver, along with signal transducer and activator of transcription factor $1 \alpha$ (STAT1) (41, 59-62). Interestingly, Koeppel et al. have noted that $\mathrm{CCl}_{4}$-mediated liver injury led to the activation of transcription factors (NF-kB, STAT1), resulting in further aggravation upon reperfusion (57).

Glutathione (GSH). Endogenous GSH concentrates intracellularly and is oxidized during reperfusion, forming glutathione disulfide (GSSG) $(63,64)$. In lean organs, GSH administration following 60, 90, or 120 minutes of ischemia or liver transplantation, attenuates rodent IRI $(65,66)$. Pratchke et al. have shown that intravenous administration of GSH, in order to achieve supraphysiological levels in hepatocytes, ameliorated IRI in both lean and steatotic livers. They postulated that most of the GSH reacted with ROS, therefore, GSSG was also found to be increased after GSH administration $(44,67)$. This is related to improved sinusoidal perfusion, decreased leukocyte adhesion and reduction of sinus endothelial cell injury in lean organs (66, $68,69)$. Glycine, a product of GSH metabolism, has also hepatoprotective properties (70).

Endoplasmic reticulum (ER). ER function consists mainly in protein synthesis, oxidative folding and transportation, calcium storage and cellular stress detection. The accurate folding of proteins requires energy. The use of molecular oxygen produces ROS and oxidized glutathione, resulting in oxidative stress. In general, a disturbance in the redox homeostasis of the ER produces ER stress and ROS $(70,71)$. ROS are also increased through ER-released calcium which concentrates in the matrix of the mitochondria, depolarizes the inner mitochondrial membrane and disrupts electron transport (73). Mitochondrial ROS may further sensitize ER calcium-releasing channels. Aside from ROS and the release of calcium, the ER relates to inflammation through the unfolded-protein response (UPR) and other signaling pathways, involving the activation of NF-kB, JUN Nterminal kinase (JNK) and the initiation of an acute-phase response to inflammation. Conditions such as obesity, contribute to alterations in liver architecture, increased protein synthesis and different cellular energy pathways, which increase the demands on the ER $(74,75)$. Therefore, ER stress is related to the emergence of hepatic steatosis, hepatocellular injury and fibrosis. Nonetheless, when Henkel et al. used chemical chaperons to reduce ER stress in methionine- and choline-deficient (MCD) diet, they found that ER stress does not have a primary role in the pathogenesis of steatohepatitis (76).

Chaperonins. They are small molecules, belonging to the large class of chaperones, which contribute to protein folding and structure and therefore stabilize the unfolded proteins $(75,77)$. IRI disrupts cellular homeostasis and, as a result, unfolded proteins accumulate. A proteomic study performed by Tiriveedhi et al. has shown significant down-regulation of multiple chaperones upon IRI in steatotic liver, which may contribute to the augmented levels of ER stress and, subsequently, in apoptosis and necrosis observed in livers with steatosis, in contrast to lean ones (78). However, Henkel et al., have shown that chemical chaperones inhibit the ER stress response without reducing hepatic steatosis in MCD diet-fed mice (76).

Selectins. They are a family of lectin-like glycoproteins and adhesion molecules that initiate the rolling and attachment of leukocytes to the vascular intima. During early IRI, P- and E-selectins are produced by activated endothelial cells, while L-selectin is expressed by all classes of leukocytes. On this basis, Amersi et al. introduced the application of soluble recombinant selectin glycoprotein ligands to fatty livers as a new method against IRI $(79,79)$. In lean livers, application of a soluble recombinant form of P-selectin glycoprotein ligand-1 (PSGL-1) impedes the interaction of P-selectin with membrane-associated PSGL-1, leading to reduced polymorphonuclear leukocytes (PMN) penetration, improved liver survival and hepatocyte injury.

Interleukins. i. IL-1 promotes the inflammatory processes by up-regulating ROS production $(22,81,82)$. Impediment of IL-1 has been found to reduce IRI in non-steatotic livers (22, 81, 83-85). Specifically, Serafin et al. have found that IL- $1 \alpha$ probably does not contribute to hepatic IRI, because IL- $1 \alpha$ levels were similar in lean and steatotic livers, at 6 hours of reperfusion when $70 \%$ of the liver had subjected to $60 \mathrm{~min}$ of ischemia. Conversely, IL-1 $\beta$ 's values were two-fold higher in the fatty livers compared to lean livers. ii. IL-6 is a multifunctional cytokine which is increased in the plasma and peripheral blood monocytes in cases of obesity. It is 
correlated both with the development and the severity of hepatic diseases, as increasing evidence indicates IL-6's importance in promoting liver regeneration and therefore protecting against injury in lean liver (86-101). Liver regeneration depends upon IL-6 activity; reduction of this cytokine may result in graft failure, in both lean and steatotic livers $(79,102)$. Hong et al. have found that long term treatment with IL-6 alleviates steatosis, and IRI and normalizes serum aminotransferase activity. They concluded that the in vivo effect of IL-6 on hepatic triglycerides is mediated by indirect mechanisms, such as down-regulation of hepatic TNFa expression, reduction in serum TNFa levels or upregulation of hepatic peroxisome proliferator-activated receptor. Tacchine et al. have suggested that the study of transcription factors that trigger the production of IL- 6 , could lead to the identification of possible molecular events that may impair its protective effect on IRI in fatty livers (102). Similarly, Jimenez-Castro et al. have considered the use of adipocytokines (IL-6, leptin etc.) as indicators of steatosis' grading and liver injury; they proposed i.e. that adipocytokines could help recognize marginal steatotic livers and assess postoperative liver injury (104). iii. IL-10 is hepatoprotective and augments allograft survival following liver transplantation $(22,105-107)$. This quality has been confirmed for endogenous IL-10 in lean livers, but the effects of exogenous IL-10 depend on its dosage. Serafin et $a l$. have related hepatoprotection seen by high doses of exogenous IL-10 to the decreased release of IL-1 $\beta$ (22). Also, they have found that exogenous IL-10 was not accumulated in fatty livers, concluding that the observed imbalance of pro- and anti-inflammatory ILs in IRI of steatotic livers could be involved in their decreased tolerance. The above IL changes are listed in Table II.

Kupffer cells (KCs). KCs are activated liver macrophages found in liver's sinusoids, and the major source of ROS and pro-inflammatory mediators $(109,110)$. To better understand their function, Mustafa SB and Olson MS treated rat KCs with lipopolysaccharide. They showed that rat KCs produced great quantities of nitrite and nitrate, synthesized and released several cytokines, which stimulated neighboring hepatocytes to produce NO resulting in degenerative changes (111-112). In total IR, KCs reduced hepatic IRI and inflammation. In lean livers, KCs may maintain a homeostatic level of inflammation through the production of IL-10 (114). Dysregulated inflammatory responses are even more important for IRI in steatotic livers. Phagocytically active KCs seem to be hepatoprotective in livers with steatosis. Sutter et al. pretreated lean and genetically obese mice with IL-10 or the liposomally-encapsulated bisphosphonate clodronate, which depletes KCs, before total IR. They found that KCs' depletion sensitizes steatotic livers to IRI through non-IL-10-dependent mechanisms.
Table II. Interleukin changes in rodent models of lean and steatotic liver after IRI.

\begin{tabular}{lccc}
\hline Interleukins & \multicolumn{2}{c}{ Liver } & References \\
\cline { 2 - 3 } & \multicolumn{2}{c}{ Lean } & Steatotic \\
\hline IL-1 $\alpha$ & \multicolumn{2}{c}{ Same levels } & $81-83$ \\
IL-1 $\beta$ & Increased & Doubled & $22,81-85$ \\
IL-6 & Normal & Decreased & $86-104$ \\
IL-10 & Increased & Non-significant & $22,105-108$ \\
& & Increase & \\
\hline
\end{tabular}

Caspases. They are a family of proteases essential for inflammation and programmed cell death. In the extrinsic signaling pathway of apoptosis, TNFa and Fas ligand promote the binding of procaspase 8 , and activate caspase 8 and procaspase 3 leading to apoptosis $(115,116)$. In the intrinsic pathway, MPT causes cytochrome c release, activation of caspase 9 and subsequently of caspase 3 (116118). Suzuki et al. have found that caspase 8 did not differ between lean and fatty livers. On the contrary, caspases 9 and 3 were further increased in fatty livers after IRI, indicating the importance of MPT. Furthermore, it is known that the intrinsic pathway occurs in hepatocytes and induces apoptosis faster than the extrinsic pathway. When the caspase cascade is inhibited, lean liver is significantly protected and IRI is reduced, while apoptosis in fatty liver is also reduced, with no change in the degree of necrosis (10). In a study by Jiang et al., significant differences were observed in malondialdehyde (MDA), superoxide dismutase (SOD) and myeloperoxidase (MPO) concentrations between lean and fatty rat liver groups (119). MDA is known to result from free radical lipid peroxidation and thus is a marker of ROS (120). SOD participates in the balance between oxidants and antioxidants, so it represents tissues' ability to discharge free radicals (121). Instead, MPO is mainly expressed in neutrophil granulocytes, so its activity indicates the quantity of neutrophils (122). The increase of MDA and MPO levels and the decrease in SOD in the fatty liver group, concur with a more severe IRI in the steatotic liver, and its hepatocytes are more sensitive to lipid peroxidation and ROS (119).

Following IRI in lean and fatty livers, higher serum alanine transaminase (ALT) levels are observed in fatty livers, representing more severe liver IRI, even when different methods of implementing fatty livers are chosen $(39,86,123)$. According to Kostakis et al. there is a steady augmentation of ALT and aspartate transaminase (AST) serum levels after hepatic ischemia in both lean and steatotic livers during the first 24 postoperative hours. Transaminases' levels remain significantly higher at 24 hours in steatotic livers (124). 
Table III. Main histopathological changes in lean and steatotic liver regarding IRI.

\begin{tabular}{|c|c|c|c|}
\hline \multirow[t]{2}{*}{ Phase } & \multirow[t]{2}{*}{ Change } & \multicolumn{2}{|c|}{ Liver } \\
\hline & & Lean & Fatty \\
\hline \multirow[t]{5}{*}{ Control conditions } & Macrovesicular fatty change & Minor & Mainly pericentral \\
\hline & Microvesicular fatty change & - & Predominant \\
\hline & Hepatocyte swelling & - & $\sqrt{ }$ \\
\hline & Nuclei density & Significantly lower & \\
\hline & Sinusoidal density & & Significantly lower \\
\hline \multirow{6}{*}{$\begin{array}{l}\text { End of ischemic period } \\
\text { Soon after reperfusion }\end{array}$} & & Vacuolization or ballooning & Small foci of hepatocyte necrosis \\
\hline & & - Vacuolar abnormalities & \\
\hline & & - Endothelial lining separation & \\
\hline & & - Moderate sinusoidal congestion & \\
\hline & & - Lobular architecture maintained & \\
\hline & Nuclei density & \multicolumn{2}{|c|}{ Not statistically significant } \\
\hline \multirow[t]{10}{*}{ Later in reperfusion } & & - Sinusoidal congestion resolved & - Pyknotic or karyorrhectic nuclei \\
\hline & & - Sinusoidal lining maintained & all over the lobule \\
\hline & & & - Sinusoids dilated significantly \\
\hline & & & $\begin{array}{l}\text { - Red blood cells in fat globules- } \\
\text { extravagation }\end{array}$ \\
\hline & & & $\begin{array}{l}\text { - Sinusoidal architecture failure } \\
\text { (periportal) }\end{array}$ \\
\hline & Sinusoidal density & \multicolumn{2}{|c|}{$\begin{array}{l}\text { - Progressive decrease-statistically significant after } 30 \mathrm{~min} \text { of reperfusion } \\
\text { - Not significant between lean-fatty liver }\end{array}$} \\
\hline & Leukocyte infiltration & $\begin{array}{l}\text { - Not significant between lean-fatty } \\
\text { - Modest inflammatory-neutrophil } \\
\text { infiltration throughout the parenchyma } \\
\text { - 3-fold }\end{array}$ & $\begin{array}{l}\text { - Increased multifocal infiltration } \\
\text { of neutrophils and lymphocytes } \\
\text {-4-fold }\end{array}$ \\
\hline & & \multicolumn{2}{|c|}{ Not statistically significant } \\
\hline & & \multicolumn{2}{|c|}{ Leukocyte adherence increases with time after reperfusion } \\
\hline & IRI necrosis & $\begin{array}{l}\text { Minor coagulative or large acute } \\
\text { necrotic areas around central veins }\end{array}$ & $\begin{array}{l}\text { Diffuse hemorrhagic-confluent areas of } \\
\text { coagulative necrosis-occasionally focal }\end{array}$ \\
\hline
\end{tabular}

\section{Microcirculatory Disorders}

Microcirculatory blood flow disorders after IR significantly affect the extent of liver injury and the prognosis of its function $(57,125)$. In normal livers, control of local sinusoidal blood flow is moderated by sinusoidal constriction in reply to inflammatory mediators, e.g. endothelin (ET-1), $\mathrm{NO}$ and carbon monoxide, which are generated within the sinusoids $(126,127)$. Alterations in the regulation and synthesis of these vasoactive mediators may result in intracellular deposits of fatty droplets in pericentral hepatocytes, which contribute to significant iNOS protein expression. The swollen hepatocytes in steatotic livers can induce chronic hypoxia, ATP depletion and increased leukocyte adhesion, resulting in decreased sinusoidal blood flow (43, 44, 128-132).

During reperfusion, regional L-arginine depletion causes reduced local NO synthesis which counteracts the effect of endothelins on liver microcirculation, resulting in hepatic sinusoidal reperfusion failure $(133,134)$. ET-1 is a peptide whose levels increase in both sinusoidal endothelial and hepatic stellate cells upon reperfusion, when TNF- $\alpha$ and other inflammatory cytokines are released by $\mathrm{KCs}$ and attach to hepatic endothelial cells $(57,135)$. The resulting extreme sinusoidal vasoconstriction may cause microcirculatory damage to the hepatic parenchyma, heterogeneous perfusion and local hypoxia that results in hepatic failure (136-140). In a study by Koeppel et al., IR induced an additional augmentation in ET-1 gene expression in most reperfused steatotic livers. As a result, it was considered that the disturbance in the sinusoidal perfusion caused by ET-1 is likely to contribute to steatotic liver IRI (57). Additionally, injection of an anti-intercellular adhesion molecule-1 monoclonal antibody, to prevent sinusoidal congestion, ameliorated only the survival rates of rodents with fatty livers $(122,141)$.

\section{Histopathological Findings}

The liver is considered fatty when its cells are steatotic in a low magnification view $(119,142)$. Specifically, hepatic steatosis of less than $30 \%$ is considered mild, 30\%- $60 \%$ moderate, and more than $60 \%$ severe $(119,143,144)$. Hepatic inflammation and fibrosis differentiate steatohepatitis from 
plain steatosis. Following MCD, rats' livers exhibit massive fatty infiltration, which is mainly macrovescicular. Fat accumulation in the cytoplasm of the hepatocytes increases cell volume, leading to various degrees of obstruction of liver sinusoids $(4,134,145)$. Therefore, sinusoids appear narrow and irregularly shaped due to compression by the fat-loaded hepatocytes. Single-cell necrosis is not often, whereas there is no inflammation and/or fibrosis.

In normal livers, IRI presents moderate early hepatocyte necrosis, minor coagulative necrosis with neutrophil infiltration, haphazardly spread throughout the liver parenchyma (22). At the end of the ischemic period, some hepatocytes are spotted with vacuolization or ballooning, while at the same time in fatty livers there are small foci of hepatocyte necrosis. In a higher magnification view, normal livers after IRI exhibit modest inflammatory infiltration in the hepatic lobule and the portal area in comparison to fatty livers. Furthermore, fatty livers present increased infiltration of neutrophils and lymphocytes. Soon after reperfusion in normal livers, focal points of necrosis, regions of vacuolar abnormalities, separation of the endothelial lining, moderate sinusoidal congestion and maintenance of the lobular architecture are observed. At this moment, the degree of sinusoidal congestion is the main histopathological difference between lean and fatty livers.

Later in reperfusion, most normal livers resolve the sinusoidal congestion, maintain their sinusoidal lining and present tiny regions of necrosis. In contrast, hepatocytes with pyknotic or karyorrhectic nuclei are dispersed all over the lobule in fatty livers, and the sinusoids dilate significantly without preserving their lining. Red blood cells are located in fat globules and diffuse hemorrhagic necrosis is present. Subsequent to sinusoidal architecture failure, red cells extravasate within large areas of the parenchyma. The alterations noted are spotty hemorrhage, hepatocyte necrosis, decreased sinusoidal density and blood flow, which lead to decreased oxygen delivery and energy metabolism $(57,131$, 146). After IRI, all livers show predominantly single cell necrosis/apoptosis, with numerous great, acute necrotic regions, mainly around the central veins, which are significantly increased in fatty livers.

Table III summarizes the main histopathological differences between lean and fatty livers before ischemia and during IRI.

\section{Fasting Effect}

Pre-ischemic fasting does not seem to have any significant effect on animal survival when the liver is normal. Even though the degree of the hepatic damage is more severe in lean livers of fasted animals, the histological findings are similar to the non-fasted ones (145).
On the contrary, pre-ischemic fasting reduces survival of rats with fatty liver tremendously. Fasting and fatty degeneration act synergistically to exacerbate hepatic IRI. Mitochondrial injury is the main characteristic of ultrastructural hepatocyte damage in fasted rodents with fatty livers. Clinically, rats with fatty liver that were fasted, took longer to recover from anesthesia, and their majority developed labored respiration and finally succumbed the following hours after reperfusion (123).

\section{Conclusion}

Ischemia-reperfusion injury consists a significant problem in liver surgery and transplantation which is aggravated by the increased prevalence of hepatic steatosis. Steatotic livers are more sensitive to IRI compared to lean livers, leading to increased postoperative graft failure, morbidity, and mortality. Moreover, the constant growth in the demand for liver donors has already led to accepting livers with moderate steatosis for transplantation, introducing potentially more postoperative complications. Therefore, additional research on IRI underlying mechanisms is needed, so that new preventive and therapeutic strategies will emerge through pharmaceutical agents, surgical interventions or gene therapy.

\section{Conflicts of Interest}

The Authors report no conflicts of interest regarding this study.

\section{Authors' Contributions}

AAN: Conception of the study, acquisition, analysis and interpretation of references, critical revision; IAD: conception of the study, supervision, critical revision and final approval of the article; DCI: critical revision, final approval of the article; TK: conception of the study, supervision, critical revision and final approval of the article.

\section{References}

1 Younossi ZM, Koenig AB, Abdelatif D, Fazel Y, Henry L and Wymer M: Global epidemiology of nonalcoholic fatty liver disease- meta-analytic assessment of prevalence, incidence, and outcomes. Hepatology 64(1): 73-84, 2016. PMID: 26707365. DOI: $10.1002 /$ hep. 28431

2 Kucera $\mathrm{O}$ and Cervinkova Z: Experimental models of nonalcoholic fatty liver disease in rats. World J Gastroenterol 20(26): 8364-8376, 2014. PMID: 25024595. DOI: 10.3748/ wjg.v20.i26.8364

3 Vernon G, Baranova A and Younossi ZM: Systematic Review: the epidemiology and natural history of non-alcoholic fatty liver disease and non-alcoholic steatohepatitis in adults. Aliment Pharmacol Ther 34: 274-285, 2011. PMID: 21623852. DOI: $10.1111 /$ j.1365-2036.2011.04724.x

4 Selzner M and Clavien PA: Fatty Liver in liver transplantation and surgery. Semin Liver Dis 21: 105-113, 2001. PMID: 11296690. DOI: $10.1055 / \mathrm{s}-2001-12933$ 
5 Mokuno Y, Berthiaume F, Tompkins RG, Balis UJ and Yarmush ML: Technique for expanding the donor liver pool: heat shock preconditioning in a rat fatty liver model. Liver Transpl 10: 264-272, 2004. PMID: 14762865. DOI: 10.1002/lt.20014

6 Koneru B, Reddy MC, de la Torre AN, Patel D, Ippolito T and Ferrante RJ: Studies of hepatic warm ischemia in the obese Zucker rat. Transplantation 59: 942-946, 1995. PMID: 7709452. DOI: $10.1097 / 00007890-199504150-00003$

7 Veteläinen R, van Vliet AK and van Gulik TM: Severe steatosis increases hepatocellular injury and impairs liver regeneration in a rat model of partial hepatectomy. Ann Surg 245: 44-50, 2007 PMID: 17197964. DOI: 10.1097/01.sla.0000225253.84501.0e

8 Selzner N, Selzner M, Jochum W and Clavien PA: Ischemic preconditioning protects the steatotic mouse liver against reperfusion injury: an ATP dependent mechanism. J Hepatol 39: 55-61, 2003. PMID: 12821044. DOI: 10.1016/s01688278(03)00147-8

9 Selzner M and Clavien PA: Resection of liver tumors: special emphasis on neoadjuvant and adjuvant therapy. In: Malignant liver tumors- current and emerging therapies. Clavien PA (ed.). Malden, MA, Blackwell Science, pp. 137-149, 1999.

10 Selzner M, Rüdiger HA, Sindram D, Madden J and Clavien PA: Mechanisms of ischemic injury are different in the steatotic and normal rat liver. Hepatology 32: 1280-1288, 2000. PMID: 11093735. DOI: $10.1053 /$ jhep.2000.20528

11 Scheele J, Stangl R and Altendorf-Hofmann A: Hepatic metastases from colorectal carcinoma: impact of surgical resection on the natural history. Br J Surg 77: 1241-1246, 1990. PMID: 2253003. DOI: 10.1002/bjs.1800771115

12 Ploeg RJ, D'Alessandro AM and Knechtle SJ: Risk factors for primary dysfunction after liver transplantation- a multivariate analysis. Transplantation 55: 807, 1993. PMID: 8475556. DOI: 10.1097/00007890-199304000-00024

13 Saidi RF, Chang J, Brooks S, Nalbantoglu I, Adsay V and Jacobs MJ: Ischemic preconditioning and intermittent clamping increase the tolerance of fatty liver to hepatic ischemia-reperfusion injury in the rat. Transplant Proc 39: 3010-3014, 2007. PMID: 18089311. DOI: 10.1016/j.transproceed.2007.09.044

14 Lee CT, Dunn RL, Chen BT, Joshi DP, Sheffield J and Montie JE: Impact of body mass index on radical Cystectomy. J Urol 172: 1281, 2004. PMID: 15371824. DOI: 10.1097/01.ju. 0000138785.48347.aa

15 Tsukada K, Miyazaki T, Kato H, Masuda N, Fukuchi M, Fukai Y, Nakajima M, Ishizaki M, Motegi M, Mogi A, Sohda M, Moteki T, Sekine T and Kuwano H: Body fat accumulation and postoperative complications after abdominal surgery. Am Surg 70: 347, 2004. PMID: 15098790.

16 Rushing GD and Britt LD: Reperfusion injury after hemorrhage: a collective review. Ann Surg 247(6): 929-937, 2008. PMID: 18520219. DOI: 10.1097/SLA.0b013e31816757f7

17 Birrer R, Takuda Y and Takara T: Hypoxic hepatopathy: pathophysiology and prognosis. Intern Med 46(14): 1063-1070, 2007. PMID: 17634701. DOI: 10.2169/internalmedicine.46.0059

18 Soleimanpour H, Safari S, Rahmani F, Nejabatian A and Alavian SM: Hepatic shock differential diagnosis and risk factors: a review article. Hepat Mon 15(10): e27063, 2015. PMID: 26587034. DOI: 10.5812/hepatmon.27063

19 Sutter AG, Palanisamy PA, Ellet JD, Schmidt MG, Schnellmann RG and Chavin KD: Intereukin-10 and Kupffer cells protect steatotic mice livers from ischemia-reperfusion injury. Eur Cytokine Netw 25(4): 69-76, 2014. PMID: 25679269. DOI: 10.1684/ecn.2015.0359

20 Mollica MP, Lionetti L, Putti R, Cavaliere G, Gaita M and Barletta A: From chronic overfeeding to hepatic injury: role of endoplasmic reticulum stress and inflammation. Nutr Metab Cardiovasc Dis 21(3): 222-230, 2011. PMID: 21277757. DOI: 10.1016/j.numecd.2010.10.012

21 Jaeschke H and Lemasters JJ: Apoptosis versus oncotic necrosis in hepatic ischemia/reperfusion injury. Gastroenterology 125 : 1246-1257, 2003. PMID: 21277757. DOI: 10.1016/j.numecd. 2010.10.012

22 Serafın A, Rosello-Catafau J, Prats N, Gelpí E, Rodés J and Peralta C: Ischemic preconditioning affects interleukin release in fatty livers of rats undergoing ischemia/reperfusion. Hepatology 39: 688-698, 2004. PMID: 14999687. DOI: 10.1002/hep.20089

23 Tiriveedhi V, Conzen DK, Liaw-Conlin J, Upadhya G, Malone J, Townsend RR, Kerns R, Jia1J, Csontos K, Ramachandran S, Mohanakumar T, Anderson DC and Chapman CW: The role of molecular chaperonins in warm ischemia and reperfusion injury in the steatotic liver: a proteomic study. BMC Biochem 13: 17, 2012. PMID: 22962947. DOI: 10.1186/1471-2091-13-17

24 Karatzas T, Neri AA, Baibaki ME and Dontas IA: Rodent models of hepatic ischemia-reperfusion injury: time and percentagerelated pathophysiological mechanisms. J Surg Res 191(2): 399412, 2014. PMID: 25033703. DOI: 10.1016/j.jss.2014.06.024

25 Eltzschig $\mathrm{HK}$ and Collard CD: Vascular ischemia and reperfusion injury. $\mathrm{Br}$ Med Bull 70: 71, 2004. PMID: 15494470. DOI: 10.1093/bmb/ldh025

26 Teoh NC and Farrell GC: Hepatic ischemia reperfusion injury: pathogenic mechanisms and basis for hepatoprotection. J Gastroenterol Hepatol 18: 891, 2003. PMID: 12859717. DOI: 10.1046/j.1440-1746.2003.03056.x

27 Zaouali AM, Ben Mosbah I, Boncompagni E, Ben Abdennebi H, Mitjavila MT, Bartrons R, Freitas I, Rimola A and RosellóCatafau J: Hypoxia inducible factor- $1 \alpha$ accumulation in steatotic liver preservation: role of nitric oxide. World $\mathrm{J}$ Gastroenterol 16(28): 3499-3509, 2010. PMID: 20653058. DOI: $10.3748 /$ wjg.v16.i28.3499

28 Chavin KD, Yang S, Lin HZ, Chatham J, Chacko VP, Hoek JB, Walajtys-Rode E, Rashid A, Chen $\mathrm{CH}$, Huang $\mathrm{CC}$, Wu TC, Lane MD and Diehl AM: Obesity induces expression of uncoupling protein-2 in hepatocytes and promotes liver ATP depletion. J Biol Chem 274: 5692, 1999. PMID: 10026188. DOI: $10.1074 / \mathrm{jbc} .274 .9 .5692$

29 Kimura K, Jung BD, Kanehira K, Irie Y, Cañas X and Saito M: Induction of uncoupling protein (UCP) 2 in primary cultured hepatocytes. FEBS Lett 457: 75, 1999. PMID: 10486567. DOI: 10.1016/s0014-5793(99)00987-4

30 Larrouy D, Laharrague P, Carrera G, Viguerie-Bascands N, Levi-Meyrueis C, Fleury C, Pecqueur C, Nibbelink M, André M, Casteilla L and Ricquier D: Kupffer cells are a dominant site of uncoupling protein 2 expression in rat liver. Biochem Biophys Res Comm 235: 760, 1997. PMID: 9207235. DOI: 10.1006/bbrc.1997.6852

31 Evans ZP, Ellett JD, Schmidt MG, Schnellmann RG and Chavin KD: Mitochondrial uncoupling protein-2 mediates steatotic liver injury following ischemia/reperfusion. J BiolChem 283: 8573, 2008. PMID: 18086675. DOI: 10.1074/jbc.M706784200 
32 Evans ZP, Mandavilli BS, Ellett JD, Rodwell D, Fariss MW, Fiorini RN, Schnellmann RG, Schmidt MG and Chavin K: Vitamin E succinate enhances steatotic liver energy status and prevents oxidative damage following ischemia/reperfusion. Transplant Proc 41(10): 4094-4098, 2009. PMID: 20005347. DOI: 10.1016/j.transproceed.2009.09.055

33 Yang S, Zhu H, Li Y, Lin H, Gabrielson K, Trush MA and Diehl AM: Mitochondrial adaptations to obesity-related oxidant stress. Arch Biochem Biophys 378: 259, 2000. PMID: 10860543. DOI: 10.1006/abbi.2000.1829

34 Echtay KS, Murphy MP, Smith RA, Talbot DA and Brand MD: Superoxide activates mitochondrial uncoupling protein 2 from the matrix side. Studies using targeted antioxidants. J Biol Chem 277: 47129, 2002. PMID: 12372827. DOI: $10.1074 /$ jbc. M208262200

35 Echtay KS, Roussel D, St-Pierre J, Jekabsons MB, Cadenas S, Stuart JA, Harper JA, Roebuck SJ, Morrison A, Pickering S, Clapham JC and Brand MD: Superoxide activates mitochondrial uncoupling proteins. Nature 415: 96, 2002. PMID: 11780125. DOI: $10.1038 / 415096 a$

36 Evans ZP, Ellett JD, Fariss MW, Schnellmann RG, Schmidt MG and Chavin K: Vitamin E succinate reduces ischemia/ reperfusion injury in steatotic livers. Transplant Proc 40: 3327, 2008. PMID: 19100382. DOI: 10.1016/j.transproceed.2008. 06.076

37 Hausenloy DJ, Yellon DM, Mani-Babu S and Duchen MR: Preconditioning protects by inhibiting the mitochondrial permeability transition. Am J Physiol 287: H841, 2004. PMID: 15072953. DOI: 10.1152/ajpheart.00678.2003

38 Teodoro JS, Rolo AP, Duarte FV, Simoes AM and Palmeira CM: Differential alterations in mitochondrial function induced by a choline-deficient diet: understanding fatty liver disease progression. Mitochondrion 8: 367, 2008. PMID: 18765303. DOI: $10.1016 /$ j.mito.2008.07.008

39 Rolo PA, Teodoro SJ, Peralta C, Rosello-Catafau J and Palmeira MC: Prevention of $\mathrm{I} / \mathrm{R}$ Injury in fatty livers by ischemic preconditioning is associated with increased mitochondrial tolerance: the key role of ATPsynthase and mitochondrial permeability transition. Transpl Int 22: 1081-1090, 2009. PMID: 19619169. DOI: 10.1111/j.1432-2277.2009.00916.x

40 Zhang J, Morris MW Jr, Dorsett-Martin WA, Drake LC and Anderson CD: Autophagy is involved in endoplasmic reticulum stress induced cell death of rat hepatocytes. Surg Res 183(2): 929-935, 2013. PMID: 23548375. DOI: 10.1016/j.jss. 2013.02.043

41 Koeppel TA, Trauner M, Mennone A, Arrese M, Rios-Velez L and Boyer JL: Role of glutathione in hepatic bile formation during reperfusion after cold ischemia of the rat liver. J Hepatol 28(5): 812-819, 1998. PMID: 9625316. DOI: 10.1016/s01688278(98)80231-6

42 Soltys K, Dikdan G and Koneru B: Oxidative stress in fatty livers of obese Zucker rats: rapid amelioration and improved tolerance to warm ischemia with tocopherol. Hepatology 34: 13-18, 2001. PMID: 11431728. DOI: 10.1053/jhep.2001.25452

43 Nardo B, Caraceni P, Pasini P, Domenicali M, Catena F, Cavallari G, Santoni B, Maiolini E, Grattagliano I, Vendemiale G, Trevisani F, Roda A, Bernardi M and Cavallari A: Increased generation of reactive oxygen species in isolated rat fatty liver during postischemic reoxygenation. Transplantation 71: 1816-1820, 2001. PMID: 11455263. DOI: 10.1097/00007890-200106270-00018
44 Pratschke S, Angele MK, Grützner U, Tufman A, Bilzer M, Loehe F, Jauch KW and Schauer RJ: GSH attenuates organ injury and improves function after transplantation of fatty livers. Eur Surg Res 45: 13-19, 2010. PMID: 20689302. DOI: $10.1159 / 000316643$

45 Prieto I and Monsalve M: ROS homeostasis, a key determinant in liver ischemic-preconditioning. Redox Biol 12: 1020-1025, 2017. PMID: 28511345. DOI: 10.1016/j.redox.2017.04.036

46 Zaouali AM, Ben Mosbah I, Boncompagni E, Ben Abdennebi H, Mitjavila MT, Bartrons R, Freitas I, Rimola A and RosellóCatafau J: Hypoxia inducible factor- $1 \alpha$ accumulation in steatotic liver preservation: role of nitric oxide. World $\mathbf{J}$ Gastroenterol 16(28): 3499-3509, 2010. PMID: 20653058. DOI: 10.3748/wjg.v16.i28.3499

47 Ben MI, Roselló-Catafau J, Franco-Gou R, Abdennebi HB, Saidane D, Ramella-Virieux S, Boillot $\mathrm{O}$ and Peralta C: Preservation of steatotic livers in IGL-1 solution. Liver Transpl 12: 1215-1223, 2006. PMID: 16724331. DOI: 10.1002/lt. 20788

48 Ben MI, Massip-Salcedo M, Fernández-Monteiro I, Xaus C, Bartrons R, Boillot O, Roselló-Catafau J and Peralta C: Addition of adenosine monophosphate-activated protein kinase activators to university of wisconsin solution: a way of protecting rat steatotic livers. Liver Transpl 13: 410-425, 2007. PMID: 17326058. DOI: 10.1002/lt.21059

49 Hon WM, Lee KH and Khoo HE: Nitric oxide in liver diseases: friend, foe, or just passerby? Ann N Y Acad Sci 962: 275-295, 2002. PMID: 12076981. DOI: 10.1111/j.1749-6632.2002. tb04074.x

50 Thomas DD, Ridnour LA, Isenberg JS, Flores-Santana W, Switzer CH, Donzelli S, Hussain P, Vecoli C, Paolocci N, Ambs S, Colton CA, Harris CC, Roberts DD and Wink DA: The chemical biology of nitric oxide: implications in cellular signaling. Free Radic Biol Med 45(1): 18-31, 2008. PMID: 18439435. DOI: 10.1016/j.freeradbiomed.2008.03.020.

51 Alexander B: The role of nitric oxide in hepatic metabolism. Nutrition. 14(4): 376-90, 1998. PMID: 9591311. DOI: 10.1016/s0899-9007(97)00492-9

52 Duranski MR, Elrod JW, Calvert JW, Bryan NS, Feelisch M and Lefer DJ: Genetic overexpression of eNOS attenuates hepatic ischemia-reperfusion injury. Am J Physiol Heart Circ Physiol 291: H2980-H2986, 2006. PMID: 16877550. DOI: 10.1152/ajpheart.01173.2005

53 Vardanian AJ, Busuttil RW and Kupiec-Weglinski JW: Molecular mediators of liver ischemia and reperfusion injury: a brief review. Mol Med 14: 337-345, 2008. PMID: 18292799. DOI: 10.2119/2007-00134.Vardanian

54 Thomas DD, Ridnour LA, Isenberg JS, Flores-Santana W, Switzer CH, Donzelli S, Hussain P, Vecoli C, Paolocci N, Ambs S, Colton CA, Harris CC, Roberts DD and Wink DA: The chemical biology of nitric oxide: Implications in cellular signaling. Free Radic Biol Med 45: 18-31, 2008. PMID: 18439435. DOI: 10.1016/j.freeradbiomed.2008.03.020

55 Duranski MR, Elrod JW, Calvert JW, Bryan NS, Feelisch M and Lefer DJ: Genetic overexpression of eNOS attenuates hepatic ischemia-reperfusion injury. Am J Physiol Heart Circ Physiol 291: H2980-H2986, 2006. PMID: 16877550. DOI: 10.1152/ajpheart.01173.2005

56 Abe Y, Hines I, Zibari G and Grisham MB: Hepatocellular protection by nitric oxide or nitrite in ischemia and reperfusion 
injury. Arch Biochem Biophys 484: 232-237, 2009. PMID: 18940177. DOI: $10.1016 /$ j.abb.2008.10.006

57 Koeppel TA, Mihaljevic N, Kraenzlin B, Loehr M, Jesenofsky R, Post $\mathrm{S}$ and Palma P: Enhanced iNOS gene expression in the steatotic rat liver after normothermic ischemia. Eur Surg Res 39(5): 303-311, 2007. PMID: 17595544. DOI: 10.1159/000104401

58 Taylor SB, de Vera ME, Ganster RW, Wang Q, Shapiro RA, Morris SM Jr, Billiar TR and Geller DA: Multiple NF-kB enhancer elements regulate cytokine induction of the human inducible nitric oxide synthase gene. J Biol Chem 273(24): 15148-15156, 1998. PMID: 9614127. DOI: 10.1074/jbc.273. 24.15148

59 Xie QW, Kashiwabara Y and Nathan C: Role of transcription factor NF-Kappa B/Rel in induction of nitric oxide synthase. J Biol Chem 269: 4705-4708, 1994. PMID: 7508926.

60 Martin E, Nathan C and Xie Q: Role of interferon regulatory factor 1 in induction of nitric oxide synthase. J Exp Med. 180: 977-984, 1994. PMID: 7520478. DOI: 10.1084/jem.180.3.977

61 Kamijo R, Harada H, Matsuyama T, Bosland M, Gerecitano J, Shapiro D, Le J, Koh SI, Kimura T, Green SJ, Mak WT, Taniguchi $\mathrm{T}$ and Vilček J: Requirement for transcription factor IRF-1 in NO synthase induction in macrophages. Science 263: 1612-1615, 1994. PMID: 7510419. DOI: 10.1126/science.7510419

62 Griscavage JM, Wilk S and Ignarro L: Inhibitors of proteasome pathway interfere with induction of nitric oxide synthase in macrophages by blocking activation of transcription factor NFkappa B. J Proc Natl Acad Sci U S A 93: 3308-3312, 1995. PMID: 8622934. DOI: 10.1073/pnas.93.8.3308

63 Lauterburg BH, Adams JD and Mitchell JR: Hepatic GSH homeostasis in the rat: efflux accounts for GSH turnover. Hepatology 4: 586-590, 1984. PMID: 6745847. DOI: 10.1002/hep.1840040402

64 Bilzer M and Lauterburg BH: GSH metabolism in activated human neutrophils: stimulation of GSH synthesis and consumption of GSH by reactive oxygen species. Eur J Clin Invest 21: 316-322, 1991. DOI: 10.1111/j.1365-2362.1991. tb01376.x

65 Bilzer M, Baron A, Schauer R, Steib C, Ebensberger S and Gerbes AL: GSH treatment protects the rat liver against injury after warm ischemia and Kupffer cell activation. Digestion 66: 49-57, 2002. PMID: 12379815. DOI: 10.1159/000064415

66 Schauer RJ, Kalmuk S, Gerbes AL, Leiderer R, Meissner H, Schildberg FW, Messmer $\mathrm{K}$ and Bilzer $\mathrm{M}$ : Intravenous administration of GSH protects parenchymal and nonparenchymal liver cells against reperfusion injury following rat liver transplantation. World J Gastroenterol 10: 864-870, 2004. PMID: 15040034. DOI: 10.3748/wjg.v10.i6.864

67 Aebi S, Assereto R and Lauterburg BH: Highdose intravenous GSH in man: pharmacokinetics and effects on cyst(e)ine in plasma and urine. Eur J Clin Invest 21: 103-110, 1991. PMID: 1907548. DOI: 10.1111/j.1365-2362.1991.tb01366.x

68 Dickinson DA and Forman HJ: GSH in defense and signaling: lessons from a small thiol. Ann NY Acad Sci 973: 488-504, 2002. PMID: 12485918. DOI: 10.1111/j.1749-6632.2002. tb04690.x

69 Schauer RJ, Gerbes AL, Vonier D, Meissner H, Michl P, Leiderer R, Schildberg FW, Messmer K and Bilzer M: GSH protects the rat liver against reperfusion injury after prolonged warm ischemia. Ann Surg 239: 220-231, 2004. PMID: 14745330. DOI: 10.1097/01.sla.0000110321.64275.95
70 Schemmer P, Bradford BU, Rose ML, Bunzendahl H, Raleigh JA, Lemasters JJ and Thurman RG: Intravenous glycine improves survival in rat liver transplantation. Am J Physiol 276: G924-G932, 1999. PMID: 10198336. DOI: 10.1152/ajpgi. 1999.276.4.G924

$71 \mathrm{Tu}$ BP and Weissman JS: Oxidative protein folding in eukaryotes: mechanisms and consequences. J Cell Biol 164: 341-346, 2004. PMID: 14757749. DOI: $10.1083 /$ jcb.200311055

72 Tu BP and Weissman JS: The FAD- and O2-dependent reaction cycle of Ero1-mediated oxidative protein folding in the endoplasmic reticulum. Mol Cell 10: 983-994, 2002. DOI: 10.1016/S1097-2765(02)00696-2

73 Gorlach A, Klappa P and Kietzmann T: The endoplasmic reticulum: folding, calcium homeostasis, signaling, and redox control. Antioxid Redox Signal 8: 1391-1418, 2006. PMID: 16986999. DOI: $10.1089 /$ ars 2006.8 .1391

74 Hotamisligil GS: Inflammation and metabolic disorders. Nature 444: 860-867, 2006. PMID: 17167474. DOI: 10.1038/ nature 05485

75 Zhang K and Kaufman JR: From endoplasmic-reticulum stress to the inflammatory response. Nature 454(7203): 455-462, 2008. PMID: 18650916. DOI: 10.1038/nature07203

76 Henkel SA, Dewey AM, Anderson KA, Olivares S and Green RM: Reducing endoplasmic reticulum stress does not improve steatohepatitis in mice fed a methionine- and choline-deficient diet. Am J Physiol Gastrointest Liver Physiol 303(1): G54-G59, 2012. PMID: 22556147. DOI: 10.1152/ajpgi.00052.2012

77 Fink AL: Chaperone-mediated protein folding. Physiol Rev 79(2): 425-449, 1999. PMID: 10221986. DOI: 10.1152/physrev. 1999.79.2.425

78 Tiriveedhi V, Conzen DK, Liaw-Conlin J, Upadhya G, Malone $\mathrm{J}$ and Townsend RR: The role of molecular chaperonins in warm ischemia and reperfusion injury in the steatotic liver: a proteomic study. BMC Biochem 13: 17, 2012. PMID: 22962947. DOI: $10.1186 / 1471-2091-13-17$

79 Amersi F, Farmer GD, Shaw GD, Kato H, Coito AJ, Kaldas F, Zhao D, Lassman CR, Melinek J, Ma J, Volk HD, KupiecWeglinski JW and Busuttil RW: P-Selectin glycoprotein ligand1 (rPSGL-Ig) - mediated blockade of CD62 selectin molecules protects rat steatotic liver grafts from ischemia/reperfusion injury. Am J Transpl 2: 600-608, 2002. PMID: 12201360. DOI: 10.1034/j.1600-6143.2002.20704.x

80 Dulkanchainun T, Goss JA, Imagawa DK, Shaw GD, Anselmo DM, Kaldas F, Wang T, Zhao D, Busuttil AA, Kato H, Murray NG, Kupiec-Weglinski JW and Busuttil RW: Reduction of hepatic ischemia/reperfusion injury by a soluble P-selectin glycoprotein ligand-1. Ann Surg 227: 832-840, 1998. PMID: 9637546. DOI: 10.1097/00000658-199806000-00006

81 Shirasugi N, Wakabayashi G, Shimazu M, Oshima A, Shito M, Kawachi S, Karahashi T, Kumamoto Y, Yoshida M and Kitajima M: Up-regulation of oxygen-derived free radicals by interleukin-1 in hepatic ischemia/reperfusion injury. Transplantation 64: 1398-403, 1997. PMID: 9392301. DOI: 10.1097/00007890-199711270-00004

82 Shirasugi N, Wakabayashi G, Shimazu M, Shito M, Kawachi S and Kitajima M: Interleukin-1 receptor blockade attenuates oxygen-derived free radical production and microcirculatory disturbances in ischemia/reperfusion injury in the liver. Transplant Proc 29: 371-373, 1997. PMID: 9123042. DOI: 10.1016/s0041-1345(96)00124-8 
83 Shito M, Wakabayashi G, Ueda M, Shimazu M, Shirasugi N, Endo M, Mukai M and Kitajima M: Interleukin-1 receptor blockade reduces tumor necrosis factor production, tissue injury, and mortality after hepatic ischemia-reperfusion in the rat. Transplantation 63: 143-148, 1997. PMID: 9000676. DOI: 10.1097/00007890-199701150-00026

84 Hashimoto K, Nishizaki T, Yoshizumi T, Uchiyama H, Okano S, Ikegami T, Yanaga K and Sugimachi K: Beneficial effect of FR167653 on cold ischemia/reperfusion injury in rat liver transplantation. Transplantation 70: 1318-1322, 2000. PMID: 11087146. DOI: 10.1097/00007890-200011150-00009

85 Kobayashi J, Takeyoshi I, Ohwada S, Iwanami K, Matsumoto $\mathrm{K}$, Muramoto M and Morishita Y: The effects of FR167653 in extended liver resection with ischemia in dogs. Hepatology 28: 459-465, 1998. PMID: 9696012. DOI: 10.1002/hep.510280225

86 Hong F, Radaeva S, Pan HN, Tian Z, Veech R, and Gao B: Interleukin-6 alleviates hepatic steatosis and ischemia/reperfusion injury in mice with fatty liver disease. Hepatology 40: 933-941, 2004. PMID: 15382116. DOI: 10.1002/hep. 20400

87 Hill DB, Marsano L, Cohen D, Allen J, Shedlofsky S and McClain CJ: Increased plasma Interleukin-6 concentrations in alcoholic hepatitis. J Lab Clin Med 119: 547-552, 1992. PMID: 1583411

88 McClain CJ, Barve S, Deaciuc I, Kugelmas M and Hill D: Cytokines in alcoholic liver disease. Semin Liver Dis 19: 205219, 1999. PMID: 22367091. DOI: 10.1007/s00204-012-0814-6

89 Hill DB, Barve S, Joshi-Barve S and McClain C: Increased monocyte nuclear factor kappa $\mathrm{B}$ activation and tumor necrosis factor production in alcoholic hepatitis. J Lab Clin Med 135: 387-395, 2000. PMID: 10811053. DOI: $10.1067 / \mathrm{mlc}$. 2000.106451

90 Kugelmas M, Hill DB, Vivian B, Marsano L and McClain CJ: Cytokines and NASH: a pilot study of the effects of lifestyle modification and vitamin E. Hepatology 38: 413-419, 2003. PMID: 12883485 . DOI: 10.1053/jhep.2003.50316

91 Cressman DE, Greenbaum LE, DeAngelis RA, Ciliberto G, Furth EE, Poli V and Taub R: Liver failure and defective hepatocyte regeneration in Interleukin-6 -deficient mice. Science 274: 1379-1383, 1996. DOI: 10.1126/science.274.5291.1379

92 Zimmers TA, McKillop IH, Pierce RH, Yoo JY and Koniaris LG: Massive liver growth in mice induced by systemic Interleukin-6 administration. Hepatology 38: 326-334, 2003. PMID: 12883476 . DOI: $10.1053 /$ jhep.2003.50318

93 Peters M, Blinn G, Jostock T, Schirmacher P, Meyer zumBüschenfelde KH, Galle PR and Rose-John S: Combined Interleukin- 6 and soluble Interleukin-6 receptor accelerates murine liver regeneration. Gastroenterology 119: 1663-1671, 2000. PMID: 11113088. DOI: 10.1053/gast.2000.20236

94 Selzner M, Camargo CA and Clavien PA: Ischemia impairs liver regeneration after major tissue loss in rodents: protective effects of interleukin-6. Hepatology 30: 469-475, 1999. PMID: 10421656. DOI: 10.1002/hep.510300215

95 Camargo CA Jr, Madden JF, Gao W, Selvan RS and Clavien PA: Interleukin-6 protects liver against warm ischemia/ reperfusion injury and promotes hepatocyte proliferation in the rodent. Hepatology 26: 1513-1520, 1997. PMID: 9397992. DOI: $10.1002 /$ hep.510260619

96 Kovalovich K, Li W, DeAngelis R, Greenbaum LE, Ciliberto $\mathrm{G}$ and Taub R: Interleukin-6 protects against Fas-mediated death by establishing a critical level of anti-apoptotic hepatic proteins FLIP, Bcl-2, and Bcl-xL. J BiolChem 276: 2660526613, 2001. PMID: 11349125. DOI: 10.1074/jbc.M100740200

97 Streetz KL, Tacke F, Leifeld L, Wüstefeld T, Graw A, Klein C, Kamino K, Spengler U, Kreipe H, Kubicka S, Müller W, Manns MP and Trautwein C: Interleukin-6/gp130-dependent pathways are protective during chronic liver diseases. Hepatology 38: 218229, 2003. PMID: 12830005. DOI: 10.1053/jhep.2003.50268

98 Blindenbacher A, Wang X, Langer I, Savino R, Terracciano L and Heim MH: Interleukin-6 is important for survival after partial hepatectomy in mice. Hepatology 38: 674-682, 2003. PMID: 12939594. DOI: 10.1053/jhep.2003.50378

99 Hong F, Kim WH, Tian Z, Jaruga B, Ishac E, Shen X and Gao B: Elevated Interleukin- 6 during ethanol consumption acts as a potential endogenous protective cytokine against ethanolinduced apoptosis in the liver: involvement of induction of Bcl2 and Bcl-x (L) proteins. Oncogene 21: 32-43, 2002. PMID: 11791174. DOI: $10.1038 /$ sj.onc. 1205016

100 Hong F, Jaruga B, Kim WH, Radaeva S, El-Assal ON, Tian Z, Nguyen VA and Gao B: Opposing roles of STAT1 and STAT3 in T cell-mediated hepatitis: regulation by SOCS. J Clin Invest 110: 1503-1513, 2002. PMID: 12438448. DOI: 10.1172/ JCI15841

101 Streetz KL, Wustefeld T, Klein C, Kallen KJ, Tronche F, Betz UA, Schütz G, Manns MP, Müller W and Trautwein C: Lack of gp130 expression in hepatocytes promotes liver injury. Gastroenterology 125: 532-543, 2003. PMID: 12891556. DOI: 10.1016/s0016-5085(03)00901-6

102 Selzner M and Clavien PA: Failure of regeneration of the steatotic rat liver: disruption at two different levels in the regeneration pathway. Hepatology 31: 35-42, 2000. PMID: 10613725. DOI: $10.1002 /$ hep.510310108

103 Tacchine 1, Cairo G, De Ponti C, Massip M, Rosellò-Catafau J and Peralta C: Up-regulation of IL-6 by ischemic preconditioning in normal and fatty rat livers: association with reduction of oxidative stress. Free Rad Res 40(11): 1206-1217, 2006. PMID: 17050174. DOI: 10.1080/10715760600885432

104 Jiménez-Castro M, Casillas-Ramírez A, Negrete-Sánchez E, Avalos-de León CG, Gracia-Sancho $\mathrm{J}$ and Peralta C: Adipocytokines in steatotic liver surgery/transplantation. Transplantation 103(1): 71-77, 2019. PMID: 30586349. DOI: 10.1097/TP.0000000000002098

105 Yoshidome $\mathrm{H}$, Kato A, Edwards $\mathrm{MJ}$ and Lentsch $\mathrm{AB}$ : Interleukin-10 suppresses hepatic ischemia/reperfusion injury in mice: implications of a central role for nuclear factor kappa B. Hepatology 30: 203-208, 1999. PMID: 10385657. DOI: 10.1002/hep.510300120

106 Yagihashi A, Hirata K, Zou XM, Tsuruma T, Araya J, Yajima T, Kameshima H, Yanai Y, Nakamura M, Wada Y, Asanuma K and Watanabe N: Down-regulation of cytokine-induced neutrophil chemoattractants and reduction of reperfusion injury in liver allograft by Interleukin-10. Transplant Proc 32: 2302, 2000. PMID: 11120174. DOI: 10.1016/s0041-1345(00)01673-0

107 Zou XM, Hirata K, Nie G, Liang YW, Zhang JG, Qin HD and Zhang B: Investigation of rhIL-10 inhibition of acute rejection after liver transplantation. Transplant Proc 32: 2123-2124, 2000. PMID: 11120097. DOI: 10.1016/s0041-1345(00)01598-0

108 Le Moine O, Louis H, Demols A, Desalle F, Demoor F, Quertinmont E, Goldman $M$ and Devière J: Cold liver ischemia-reperfusion injury critically depends on liver $\mathrm{T}$ cells 
and is improved by donor pretreatment with interleukin-10 in mice. Hepatology 31: 1266-1274, 2000. PMID: 10827152. DOI: $10.1053 /$ jhep.2000.7881

109 Zhang W, Wang M, Xie HY, Zhou L, Meng XQ, Shi J and Zheng S: Role of reactive oxygen species in mediating hepatic ischemia-reperfusion injury and its therapeutic applications in liver transplantation. Transplant Proc 39: 1332-1337, 2007. PMID: 17580134. DOI: 10.1016/j.transproceed.2006.11.021

110 Ogiku M, Kono $\mathrm{H}$, Hara $\mathrm{M}$, Tsuchiya $\mathrm{M}$ and Fujii $\mathrm{H}$ : Glycyrrhizin prevents liver injury by inhibition of high-mobility group box 1 production by Kupffer cells after ischemiareperfusion in rats. J Pharmacol Exp Ther 339: 93-98, 2011. PMID: 21737537. DOI: 10.1124/jpet.111.182592

111 Mustafa SB and Olson MS: cAMP. J Biol Chem 273(9): 50735080, 1998. PMID: 9478958. DOI: 10.1074/jbc.273.9.5073

112 Laskin DL, Rodriguez del Valle M, Heck DE, Hwang SM, Ohnishi ST, Durham SK, Goller NL and Laskin JD: Hepatic nitric oxide production following acute endotoxemia in rats is mediated by increased inducible nitric oxide synthase gene expression. Hepatology 22: 223-234, 1995. PMID: 7541386.

113 Nussler AK, Di Silvio M,Liu ZZ, Geller DA, Freeswick P, Dorko K, Bartoli F and Billiar RT: Further characterization and comparison of inducible nitric oxide synthase in mouse, rat, and human hepatocytes. Hepatology 21: 1552-1560, 1995. DOI: 10.1016/0270-9139(95)90459-X

114 Movita D, Kreefft K, Biesta P, van Oudenaren A, Leenen PJ, Janssen HL and Boonstra A: Kupffer cells express a unique combination of phenotypic and functional characteristics compared with splenic and peritoneal macrophages. J Leukoc Biol 92: 723-733, 2012. PMID: 22685319. DOI: 10.1189/ jlb.1111566

115 Suzuki T, Yoshidome H, Kimura F, Shimizu H, Ohtsuka M, Takeuchi D, Kato A, Furukawa K, Yoshitomi H, Iida A, Dochi T and Miyazaki M: Hepatocyte apoptosis is enhanced after ischemia/reperfusion in the steatotic liver. J Clin Biochem Nutr 48(2): 142-148, 2011. PMID: 21373267. DOI: 10.3164/jcbn.10-74

116 Soeda J, Miyagawa S, Sano K, Masumoto J, Taniguchi S and Kawasaki S: Cytochrome C release into cytosol with subsequent caspase activation during warm ischemia in rat liver. Am J Physiol Gastrointest Liver Physiol 281: G1115G1123, 2001. PMID: 11557532. DOI: 10.1152/ajpgi. 2001.281.4.G1115

117 Morin D, Pires F, Plin C and Tillement JP: Role of the permeability transition pore in cytochrome $\mathrm{C}$ release from mitochondria during ischemia-reperfusion in rat liver. Biochem Pharmacol 68: 2065-2073, 2004. PMID: 15476677. DOI: 10.1016/j.bcp.2004.07.006

118 Wang X: The expanding role of mitochondria in apoptosis. Genes Dev 15: 2922-2933, 2001. PMID: 11711427. DOI: $10.3164 /$ jcbn. 1074

119 Jiang Y, Tang JJ, Wu BQ, Yuan B and Qu Z: The protective effects of different-time-ischemic preconditioning on the reperfusion injury in fatty livers in rats. PLoS One 8(3): e58086, 2013. PMID: 23483973. DOI: 10.1371/journal. pone.0058086

120 Camara-Lemarroy CR, Guzman-de la Garza FJ and AlarconGalvan G: The effects of NMDA receptor antagonists over intestinal ischemia/reperfusion injury in rats. Eur J Pharmacol 621: 78-85, 2009. PMID: 19751722. DOI: 10.1016/j.ejphar. 2009.08 .038
121 Lehmann TG, Wheeler MD and Froh M: Effects of three superoxide dismutase genes delivered with an adenovirus on graft function after transplantation of fatty livers in the rat. Transplantation 76: 28-37, 2003. PMID: 12865782. DOI: 10.1097/01.TP.0000065299.29900.17

122 Rensen SS, Slaats Y and Nijhuis J: Increased hepatic myeloperoxidase activity in obese subjects with nonalcoholic steatohepatitis. Am J Pathol 175: 1473-1482, 2009. PMID: 19729473. DOI: 10.2353/ajpath.2009.080999

123 Caraceni P, Domenicali M, Vendemiale G, Grattagliano I, Pertosa A, Nardo B, Morselli-Labate AM, Trevisani F, Palasciano G, Altomare E and Bernardi M: The reduced tolerance of rat fatty liver to ischemia reperfusion is associated with mitochondrial oxidative injury. J Surg Res 124(2): 160168, 2005. PMID: 15820243. DOI: 10.1016/j.jss.2004.10.007

124 Kostakis ID, Sikalias N, Alexiou K, Mountzalia L, Papalois A and Karatzas T: How much ischemia can the severely steatotic rat liver tolerate? In Vivo 32(6): 1381-1386, 2018. PMID: 30348692. DOI: 10.21873 /invivo. 11390

125 Chun K, Zhang J, Biewer J, Ferguson D and Clemens MG: Microcirculatory failure determines lethal hepatocyte injury in ischemic/reperfused rat livers. Shock 1: 3-9, 1994. PMID: 7743324. DOI: 10.1097/00024382-199401000-00002

126 Bauer M, Zhang JX, Bauer I and Clemens MG: Endothelin-1 as a regulator of hepatic microcirculation: sublobular distribution of effects and impact on hepatocellular secretory function. Shock 1: 457-465, 1994. PMID: 7735976.

127 Rensing H, Bauer I, Zhang WJ, Paxian M, Pannen HJB, Yokoyama Y, Clemens MG and Bauer M: Endothelin-1 and heme oxygenase-1 as modulators of sinusoidal tone in the stress-exposed rat liver. Hepatology 36: 1453-1465, 2002. PMID: 12447872 . DOI: 10.1053/jhep.2002.36934

128 Seifalian AM, Piasecki C, Agarwal A and Davidson BR: The effect of graded steatosis on flow in the hepatic parenchymal microcirculation. Transplantation 68: 780-784, 1999. PMID: 10515377. DOI: 10.1097/00007890-199909270-00009

129 Serkova NJ, Jackman M, Brown JL, Liu T, Hirose R, Roberts JP, Maher JJ and Niemann CU: Metabolic profiling of livers and blood from obese Zucker rats. J Hepatol 44: 956-962, 2006. PMID: 16223541. DOI: 10.1016/j.jhep.2005.07.009

130 Teramoto K, Bowers JL, Kruskal JB and Clouse ME: Hepatic microcirculatory changes after reperfusion in fatty and normal liver transplantation in the rat. Transplantation 56: 1076-1082, 1993. PMID: 8249103. DOI: 10.1097/00007890-19931100000005

131 Sun CK, Zhang XY, Zimmermann A, Davis G and Wheatley AM: Effect of ischemia-reperfusion injury on the microcirculation of the steatotic liver of the Zucker rat. Transplantation 72: 1625-1631, 2001. PMID: 11726821. DOI: 10.1097/00007890-200111270-00008

132 Yamagami K, Hutter J, Yamamoto Y, Schauer RJ, Enders G, Leiderer R, Ozen O, Hammer C, Yamaoka Y and Messmer K: Synergistic effects of brain death and liver steatosis on the hepatic microcirculation. Transplantation 80: 500-505, 2005. PMID: 16123725. DOI: 10.1097/01.tp.0000167723.46580.78

133 Peralta C, Rull R, Rimola A, Deulofeu R, Roselló-Catafau J, Gelpí E and Rodés J: Endogenous nitric oxide and exogenous nitric oxide supplementation in hepatic ischemia-reperfusion injury in the rat. Transplantation 71: 529-536, 2001. PMID: 11258432. DOI: 10.1097/00007890-200102270-00008 
134 Rockey DC: Hepatic blood flow regulation by stellate cells in normal and injured liver. Semin Liver Dis 21: 337-349, 2001. PMID: 11586464. DOI: 10.1055/s-2001-17551

135 Rockey DC, Fouassier L, Chung JJ, Carayon A, Vallee P, Rey $\mathrm{C}$ and Housset C: Cellular localization of Endothelin-1 and increased production in liver injury in the rat: potential for autocrine and paracrine effects on stellate cells. Hepatology 27: 472-480, 1998. PMID: 9462646. DOI: 10.1002/hep.510270222

136 Kaffarnik MF, Ahmadi N, Lock JF, Wuensch T, Pratschke J, Stockmann M and Malinowski M: Correlation between plasma Endothelin-1 levels and severity of septic liver failure quantified by maximal liver function capacity (LiMAx test). A prospective study. PLoS One 12(5): e0178237, 2017. PMID: 28542386. DOI: 10.1371 /journal.pone. 0178237

137 Chan CC, Wang SS, Lee FY, Chang FY, Lin HC, Chu CJ, Chen $\mathrm{CT}$, Huang $\mathrm{HC}$ and Lee SD: Endothelin-1 induces vasoconstriction on portal-systemic collaterals of portal hypertensive rats. Hepatology 33: 816-820, 2001. PMID: 11283844. DOI: $10.1053 /$ jhep.2001.23079

138 Eakes AT and Olson MS: Regulation of Endothelin synthesis in hepatic endothelial cells. Am J Physiol 274: G1068-1076, 1998. PMID: 9696707. DOI: 10.1152/ajpgi.1998.274.6.G1068

139 McKenna S, Gossling M, Bugarini A, Hill E, Anderson AL, Rancourt RC Balasubramaniyan N, El Kasmi KC and Wright CJ: Endotoxemia induces I kappa B beta/NF-kappa Bdependent endothelin-1 expression in hepatic macrophages. J Immunol 195: 3866-3879, 2015. PMID: 26342031. DOI: 10.4049/jimmunol.1501017

140 Zhao RZ, Chen X, Yao Q and Chen C: TNF-alpha induces Interleukin-8 and Endothelin-1 expression in human endothelial cells with different redox pathways. Biochem Biophys Res Commun 327: 985-992, 2005. PMID: 15652492. DOI: 10.1016/j.bbrc.2004.12.109
141 Hakamada K, Sasaki M, Takahashi K, Umehara Y and Konn M: Sinusoidal flow block after warm ischemia in rats with dietinduced fatty liver. J Surg Res 70: 12-20, 1997. PMID: 9228921. DOI: $10.1006 /$ jsre.1997.5077

142 Federico A, Trappoliere $M$ and Loguercio C: Treatment of patients with nonalcoholic fatty liver disease: current views and perspectives. Dig Liver Dis 38: 789-801, 2006. DOI: 10.1016/j.dld.2006.04.009

143 McCormack L, Dutkowski P, El-Badry AM and Clavien PA: Liver transplantation using fatty livers: always feasible? J Hepatol 54(5): 1055-1062, 2011. PMID: 21145846. DOI: 10.1016/j.jhep.2010.11.004

144 Chu MJJ, Vather R, Hickey AJR, Phillips RJA and Bartlett ASJR: Impact of ischaemic preconditioning on experimental steatotic livers following hepatic ischaemia-reperfusion injury: a systematic review. HPB (Oxford) 17(1): 1-10, 2015. PMID: 24712641. DOI: $10.1111 / \mathrm{hpb} .12258$

145 Zaouali AM, Ben Mosbah I, Boncompagni E, Ben Abdennebi H, Mitjavila MT, Bartrons R, Freitas I, Rimola A and RosellóCatafau J: Hypoxia inducible factor- $1 \alpha$ accumulation in steatotic liver preservation: role of nitric oxide. World $\mathrm{J}$ Gastroenterol 16(28): 3499-3509, 2010. PMID: 20653058. DOI: $10.3748 / w j g . v 16 . i 28.3499$

146 Hui AM, Kawasaki S, Makuuchi M, Nakayama J, Ikegami T and Miyagawa S: Liver injury following normothermic ischemia in steatotic rat liver. Hepatology 20: 1287-1293, 1994. PMID: 7927264. DOI: 10.1002/hep.1840200528

Received January 22, 2020

Revised February 3, 2020

Accepted February 7, 2020 